[計 測 自 動 制 御 学 会 論 文 集

[ Vol.48, No.12, 854/862 (2012) ]

\title{
箔状圧電センサを利用した頸髄損傷患者のためのPC 操作インタフェース
}

\author{
島圭 介*・杉 江 研 勇**·芝 軒 太 郎**・卜楠** \\ 上 野 直 広****.吉 栖 正 生*·过敏 夫**
}

A Personal Computer Control Interface with Flexible Piezoelectric Thin Film Sensors

for Individuals with Paralysis from Cervical Cord Injuries

Keisuke Shima*, Akitoshi Sugie**, Taro Shibanoki**, Nan Bu***,
Naohiro Ueno ${ }^{* * * *}$, Masao Yoshizumi* and Toshio Tsuji ${ }^{* *}$

\begin{abstract}
This paper proposes a novel method of measuring muscle surface deformation using flexible piezoelectric thin film sensors to allow PC operation by people with severe physical disabilities. Piezoelectric signals are first measured using thin film sensors that are flexible, compact and sensitive. Strength and velocity information relating to muscle surface deformation is extracted from the signals measured and used as input for a neural network. In this way, the motions of users can be estimated by learning differences in muscle surface deformation information for particular individuals. A PC can also be operated with only a few motions if an assistive operation mode is introduced. This paper details the development of a mask-type interface with piezoelectric thin film sensors and outlines experiments conducted on the measurement of muscle surface deformation. The results showed that multiple facial motions can be discriminated accurately from the muscle deformation information obtained. PC operation experiments involving three subjects (including one with paralysis from a cervical cord injury) also produced outcomes indicating that a PC can be operated voluntarily based on facial motions by people with severe physical disabilities.
\end{abstract}

Key Words: piezoelectric sensor, PC control interface, muscle surface movement, neural network, patients with cervical cord injury

\section{1. はじめに}

日常生活で使用する家電機器のリモコンなどに代表される ようなインタフェースは手や指先などの細かい動きを必要と するものが多く, 頸髄損傷患者のような重度の肢体不自由者 は使用が困難な場合がある。そのため，障害の度合いによら ずに使用可能な新しいインタフェースが望まれる。

特にパーソナルコンピュータ (PC) は一般家庭に広く普及 しており，インターネットショッピングやホームページの閲

$*$ 広島大学大学院医歯薬学総合研究科 広島市南区霞 $1-2-3$

** 広島大学大学院工学研究科 東広島市鏡山 1-4-1

*** 熊本高等専門学校制御情報システム工学科 合志市須屋 2659-2

**** (独) 産業技術総合研究所 鳥栖市宿町 807-1

* Graduate School of Biomedical Sciences, Hiroshima University, 1-2-3 Kasumi, Minami-ku, Hiroshima

** Graduate School of Engineering, Hiroshima University, 1-4-1 Kagamiyama, Higashihiroshima

*** Graduate School of Engineering, Kumamoto National College of Technology, 2659-2 Suya, Koshi

**** National Institute of Advanced Industrial Science and Technology, 807-1 Shukumachi, Tosu

(Received February 27, 2012)

(Revised June 13, 2012)
覧，メール送受信などを実施できるインタフェースは重度肢 体不自由が在宅しながら社会生活を営む上で必要不可欠なコ ミュニケーションツールになり得る。

肢体不自由者の残存機能を活用して各種機器を制御可能な インタフェースとして, 脳波 (Electroencephalogram; 以下, EEG）や筋電位 (Electromyogram; 以下, EMG) などの生 体電気信号を用いた研究が数多く行なわれてきた ${ }^{1) ~ 5)}$. たと えば EEG 信号を利用した PC 制御 ${ }^{1)}$ や電動車椅子の制御 ${ }^{2)}$, EMG 信号を用いた文字入力システム ${ }^{4)}$ や環境制御装置 ${ }^{5)}$ ど枚挙にいとまがない。これらは筋収縮や脳活動におけるさ まざまな情報を用いて機器制御できる反面, 計測装置が大規 模になることや電極貼付のわずらわしさなど，重度肢体不自 由者が日常的に用いるには課題が多く残されている。

ここで, 重度肢体不自由者が日常的に PC を使用すること を考えると，インタフェースの入力信号は，(1) 操作者の残存 機能を有効活用でき，(2) 信号計測に用いるセンサが小型・軽 量で操作者への着脱が容易なことが望ましい．また，(3) 長 時間の使用時に想定される発汗などの皮膚インピーダンスの 影響を受けない必要がある。そして, PC 操作の実現には (4) ポインタやイベント制御，およびテキストの入力を随意的に 実行できる必要がある。さらに，(5) 操作者個々の個人差を 
インタフェースシステムが学習でき, 用途や残存機能にあわ せて操作方法を変更できる機能があれば有用である.

一方, 軽量・着脱容易で，かつ肢体不自由者も利用可能なイ ンタフェースはすでにいくつか提案されており ${ }^{6) \sim 8) ， た と え ~}$ ばカメラを用いて計測した視線情報から車椅子の操作 ${ }^{6)}$ を試 みた研究や眼電図を用いたゲームインタフェース7)などがあ る。また，光学式距離センサをへッドフォンに取り付け，瞬 きを行なった際の表皮変動から音楽プレーヤーの操作を実現 したインタフェース ${ }^{8)}$ も提案されている。 しかしながら，こ のインタフェースは動作の識別に用いる闇値が全操作者共通 であるため，操作者が随意的に動作を実施できない場合には 識別精度が低下してしまう。また，これまでに開発されたイ ンタフェースでは機器操作に必要な動作数があらかじめ決め られており, 識別可能動作数が少ない被験者は機器の操作を 行なえない可能性がある，さらに，(1)～(5) のすべてを解決 した重度肢体不自由者のためのインタフェースシステムはこ れまで提案されていない.

そこで本論文では，箔状圧電センサ ${ }^{9}$ )を用いた筋の動き（筋 動と呼ぶ）の計測法を提案し,

1. 計測した筋動信号の情報から操作者の筋動の強さと速 さの傾向を推定する特徵抽出法

2. ニューラルネットを用いた筋動情報の学習と多動作識 別法

3. 操作者の実施可能な動作数に合わせた複数のコントロー ルモード

を導入した重度肢体不自由者のための $\mathrm{PC}$ 操作インタフェー スシステムを開発する。箔状圧電センサはセンサに加わる圧 力変動を計測可能であり，非常に柔軟で高感度であるため生 体表面のわずかな圧力変動を検出できる ${ }^{10)}$ ，また，このセン サは小柄かつ軽量でさまざまな物体に容易に取り付けること ができ，皮膚インピーダンスの影響を受けずに筋動情報を計 測可能である。提案システムでは確率ニューラルネットを用 いることでセンサの貼付位置や個人差による信号レベルの変 化を学習し, 操作者の動作を推定する.これにより, 動作識 別の際にエントロピー ${ }^{5)}$ や閾值処理を利用して，意図しない 動作による誤動作防止をすることが可能である。また PC の 操作方法に複数の制御モードを導入することにより，重度肢 体不自由者が少ない動作数でポインタ/イベント制御やテキ スト入力を行なえる.

以下， 2 章では箔状圧電センサと筋動信号計測法について 述べ， 3 章で提案するシステムについて説明する。そして，4 章および 5 章では提案システムを用いた実験によりその有効 性を示す。

\section{2. 箔状圧電センサ 9) を用いた筋動信号計測法}

Fig. 1 (a) に䇴状圧電センサの概観，(b) に構造図を示す. 箔状圧電センサは高 $\mathrm{C}$ 軸配向性窒化アルミニウム (Aluminum nitride；以下，AlN）薄膜を用いて圧力計測を行なう。高 C 軸配向性 AlN 薄膜は優れた熱特性をもち, $1150{ }^{\circ} \mathrm{C}$ まで圧電

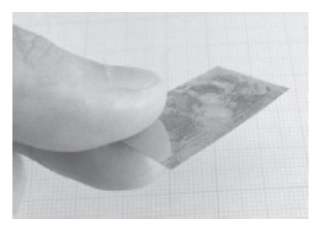

(a) Overview

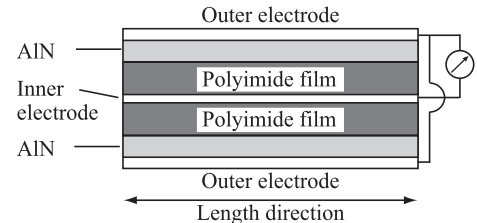

(b) Structure
Fig. 1 Proposed piezoelectric sensor

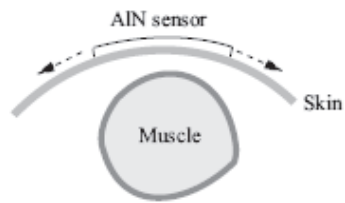

Fig. 2 A schematic view of the signal acquisition an AlN sensor attached to skin surface

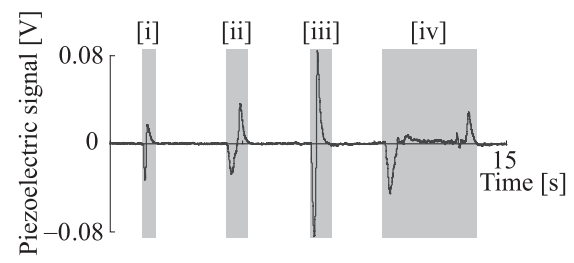

Fig. 3 An example of output signals of a piezoelectric sensor

性を保持することができる．䇴状圧電センサは (b) に示すよ うに 3 枚の白金電極とポリアミドを付加した 2 層の AlN 薄 膜層が交互に積層したラミネート構造を採用しており，厚さ は約 $50 \mu \mathrm{m}$ である.ラミネート構造を用いることで内側の 1 枚の内部電極が外側の 2 枚の外部電極によって外部環境から 完全に遮蔽されるため, 発生電荷の外部へのリーク防止と誘 導電荷の抑制に効果があり，人体のような導体と直接接触し ても正確な発生電荷の検出が可能である．䇴状圧電センサは 圧電体である AlN の圧電性を動作原理としているため，印加 圧力によって AlN 表面に生じた電荷が出力となる.

Fig. 2 に箔状圧電センサを筋付近の皮膚表面に貼付し, 対 応する筋を収縮させた際にセンサに生じる形状変化を示す。 図のようにセンサを皮膚表面に貼付した場合，筋収縮により センサに圧力が加わりセンサの形状が変化する。これにより， センサ内部では分極が発生し, 電位差が生じて電流が流れる. この方法を用いることで，皮膚表面から箔状圧電センサを用 いて筋の動きの情報（筋動）を計測可能である。

また，箔状圧電センサを左㚘に医療用テープで貼付し，㚘 を動かすことで得られた電圧波形を Fig. 3 に示す。図中の 陰影部は㚘を動かしてからもとに戻すまでの一連の動作を行 なった区間である。それぞれ㚘を [i] 小さく動かす，[ii] 大き く動かす, [iii] 素早く動かす, [iv] 大きく動かしてその状態を 維持した後，もとに戻した区間を示している．図のように㚘 を動かす際と戻す際に圧力変動が計測でき，煩を動かす大き さの違い（[i]，[ii]）や速さの違い（[i]，[iii]）において電圧值

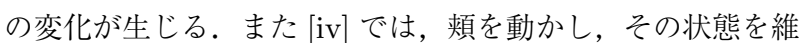
持し続けているにもかかわらず，煩を動かす瞬間と戻す瞬間 


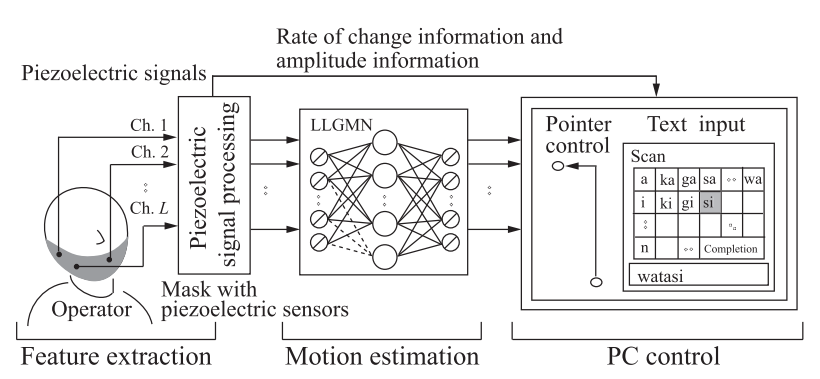

Fig. 4 Overview of the proposed PC interface system

のみ大きな電圧変化がみられ, 状態を維持した場合の電圧值 はほぼ $0 \mathrm{~V}$ である。このように䇴状圧電センサは圧力そのも のではなく，圧力の変化率を計測する.

以上のようにして計測した筋動情報をインタフェースの入 力信号として用いるためには, 得られた圧力変動から筋収縮 の速さ, 各筋の収縮パターンなど強さの特徵を抽出し, そこ から操作者の実施した動作を推定できる必要がある.さらに, 操作者が随意的に実施可能な動作を用いてさまざまな $\mathrm{PC}$ 操 作のコマンドを選択できる方法論が必要である. 次章では, 提案する筋動情報を用いた $\mathrm{PC}$ 操作インタフェースの詳細に ついて述べる。

\section{3. 筋動情報による PC 操作システム}

Fig. 4 に箔状圧電センサを利用した PC 操作システムの構 成を示す. 提案システムは特徵抽出部, 動作推定部, $\mathrm{PC}$ 操作 部の 3 つから構成される. 特徵抽出部では, 䇴状圧電センサ を用いて計測した筋動情報から振幅情報などを抽出する．動 作推定部ではニューラルネットを用いて操作者の動作を推定 し, PC 操作部において識別結果に対応した $\mathrm{PC}$ 操作を実行 する．以下，各部の詳細を示す．

\section{1 特徵抽出部}

特徵抽出部では, 操作者から計測した筋動情報から動作ご との素早さの傾向を表わす変化率情報, 力強さの傾向を表わす 振幅情報, および動作時の筋動パターンベクトルを抽出する.

䈃状圧電センサから測定した $L$ チャネルの筋動情報を $\mathrm{A} / \mathrm{D}$ 変換（サンプリング周波数: $\left.f_{s}[\mathrm{~Hz}]\right)$ し, 得られる時系列信 号を $E_{l}(t)(l=1,2, \cdots, L)$ とする。このとき， $E_{l}(t)$ に対し て不感帯を導入し, 次式に定義する処理を行なう。

$$
E_{l}^{\prime}(t)=\left\{\begin{array}{cc}
E_{l}(t)-V_{\mathrm{th}}^{+} & \left(E_{l}(t)>V_{\mathrm{th}}^{+}\right) \\
0 & \left(V_{\mathrm{th}}^{-} \leq E_{l}(t) \leq V_{\mathrm{th}}^{+}\right) \\
E_{l}(t)-V_{\mathrm{th}}^{-} & \left(E_{l}(t)<V_{\mathrm{th}}^{-}\right)
\end{array}\right.
$$

これにより, 操作者が意図していない動作によって生じる微 小な変動を除去する. 動作の素早さの傾向を表わす変化率情 報 $F_{V}(t)$ は， $E_{l}^{\prime}(t)$ を用いて次式で算出する.

$$
F_{V}(t)=\frac{1}{L} \sum_{l=1}^{L} \frac{\left|E_{l}^{\prime}(t)\right|}{E_{l}^{\prime} \max } \quad(l=1,2, \cdots, L)
$$

ここで, $E_{l}^{\prime}{ }^{m a x}$ は事前に計測した $E_{l}^{\prime}(t)$ の絶対值の最大值で
ある・

つぎに動作の力強さの傾向を表わす振幅情報 $F_{I}(t)$ を抽出す るため, $E_{l}^{\prime}(t)$ に対してチャネルごとに (3), (4) 式に示す台形積 分法による積分処理を施し, 積分情報 $I_{l}(t)(l=1,2, \cdots, L)$ （積分時間： $\frac{1}{f_{s}}[\mathrm{~s}]$ ) を求める.

$$
\begin{aligned}
& T_{l}(t)=\frac{1}{2 f_{s}}\left(E_{l}^{\prime}(t)+E_{l}^{\prime}(t-1)\right) \\
& I_{l}(t)=\left|T_{l}(t)+T_{l}(t-1)\right|
\end{aligned}
$$

ただし，積分処理においては $I_{l}(t)$ の立ち上がり幅と立ち下 がり幅が一致しない場合に $I_{l}(t)$ の值が 0 に戻らないことが あるため，次式のように不感帯を設定する.

$$
I_{l}^{\prime}(t)=\left\{\begin{array}{cl}
I_{l}(t) & \left(E_{l}(t) \geq V_{\mathrm{th}}^{-}\right) \\
0 & \left(E_{l}(t)<V_{\mathrm{th}}^{-}\right)
\end{array}\right.
$$

そして, 算出した $I_{l}^{\prime}(t)$ から振幅情報 $F_{I}(t)$ を定義する.

$$
\begin{aligned}
& F_{I}(t)=\frac{1}{L} \sum_{l=1}^{L} \alpha_{l}(t) \\
& \alpha_{l}(t)=\frac{I_{l(t)}^{\prime}}{I_{l}^{\prime}(t)^{\max }}(l=1,2, \cdots, L)
\end{aligned}
$$

なお， $\alpha_{l}(t)$ は $I_{l}^{\prime}(t)$ の最大值がチャネルごとに 1 となる ように正規化したものであり， $I_{l}^{\prime}(t)^{\max }$ は事前に計測した $I_{l}^{\prime}(t)$ の最大值を表わす。 その後, 全チャネルの和が 1 とな るように次式を用いて正規化したものをパターンベクトル $\boldsymbol{x}(t)=\left[x_{1}(t), x_{2}(t), \cdots, x_{L}(t)\right]^{\mathrm{T}}$ として, 動作推定部へ入力 する.

$$
x_{l}(t)=\frac{\alpha_{l}(t)}{\sum_{l^{\prime}=1}^{L} \alpha_{l^{\prime}(t)}}
$$

\section{2 ニューラルネットによる動作推定部}

動作推定部では Tsuji らが提案した LLGMN ${ }^{11)}$ を用いて 操作者の動作を推定する．LLGNM は混合ガウス分布モデル (Gaussian mixture model; 以下, GMM) を対数線形化して ネットワークに展開しており, サンプルデータが従う統計分 布を学習的に推定し, 入力パターンの各クラスに対する事後確 率を算出できる。LLGMN の学習能力により，個人差による 信号の違いやセンサ位置のずれなどによる信号変化に対応で き, EMG や EEG などを高精度に識別可能である ${ }^{4), 5), 11)}$. ここでは, LLGMN に筋動情報を入力して操作者の動作推定 を試みる。

まず，あらかじめ操作者に複数の動作を行なわせ，動作ご とのパターンベクトルを LLGMN に学習させる．学習後の LLGMN に新たなパターンベクトル $\boldsymbol{x}(t)$ を入力することで, 操作者が行なった動作が学習動作のどれに属するかを事後確 率 $p(k \mid \boldsymbol{x}(t)) \quad(k=1, \cdots, K ; K$ は動作数）として算出する. 動作の決定には LLGMN の事後確率, および振幅情報 $F_{I}(t)$ を用いる．あらかじめ動作判定闇值 $F_{\mathrm{th}}$ を設定しておき，振 


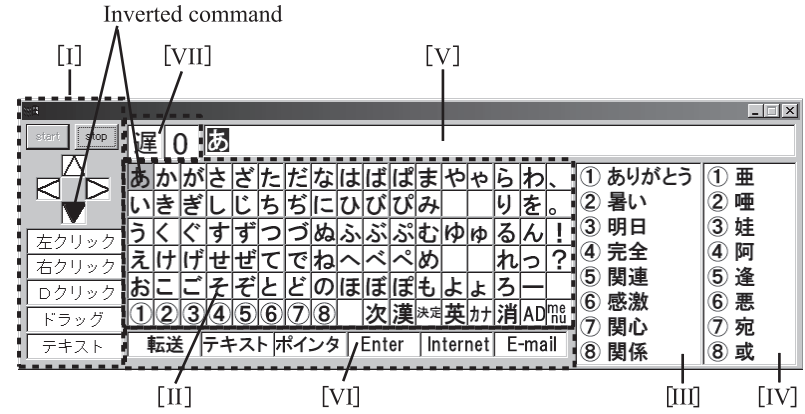

Fig. 5 Control panel of the proposed system

幅情報 $F_{I}(t)$ が $F_{I}(t)>F_{\mathrm{th}}$ となったときに識別を開始する. この際, あいまいな識別による誤識別を防止するために次式 のエントロピーを利用して識別判定処理を行なう ${ }^{5)}$.

$$
H(t)=-\sum_{k=1}^{K} p(k \mid \boldsymbol{x}(t)) \log p(k \mid \boldsymbol{x}(t))
$$

この $H(t)$ を設定した閾值 $H_{\mathrm{th}}$ と比較し, $H(t)<H_{\mathrm{th}}$ で あれば出力 $p(k \mid \boldsymbol{x}(t))$ が最大となる動作を識別結果とする. $H(t) \geq H_{\mathrm{th}}$ の場合はあいまいな動作として識別を保留する. さらに動作回数閾值 $O_{\mathrm{th}}$ 設定し, 識別された動作 $k$ が $O_{\mathrm{th}}$ 回 連続したときにのみ， $k$ を動作として決定する.

\section{3 PC 操作部}

$\mathrm{PC}$ 操作部はポインタ制御（ポインタ移動，イベント操作） とテキスト入力の 2 つから構成される．操作者は識別した動 作を利用して Fig. 5 に示す操作パネル中のコマンドを実行 し, PC を操作する. なお, 現在選択されているコマンドは 反転表示される（図中の反転表示部. 以下，反転コマンドと 呼ぶ). 提案システムは, 操作者が実施可能な動作数 $K$ に応 じて操作方法を 3 つのモードから自由に変更可能である.

(1) ポインタ制御

Fig. 5 の [I] に示される操作メニューでは, ポインタ移動や クリックなどのイベント操作を実行できる. Fig. 5 の [I] の 4 つの記号は上下左右のポインタの移動コマンドを表わし, そ の下に並ぶ“左クリック”などのコマンドはマウスのイベン トに対応する。なお “D クリック”はダブルクリック，“テキ スト”は Fig. 5 の [II] に示されるテキスト入力モードへの移 行を表わすコマンドである.

・ 1 動作モード $(K=1)$

操作者がただ 1 つの動作のみ実施可能な場合は, 反転コマ ンドが一定時間で自動的に切り替わるスキャンモードを用い る．操作者は自動遷移している反転コマンドが実行したいコ マンドの位置に到達したときに動作を行なうことで, 希望す るコマンドを実行することができる.

・ 2 動作モード $(K=2)$

2 つの動作を用いるメニュー選択モードでは, 第 1 の動作 （動作 1) は反転コマンドの切り替えに用い, 第 2 の動作（動作 2）は現在の反転コマンドの実行に割り当てて操作を行なう. まず操作者は動作 1 を繰り返し行ない, 反転表示されるコマ
ンドを実行したい目的のコマンド位置まで移動する，目的の コマンドで動作 2 を行なうとそのコマンドが実行され, PC へ対応する制御命令が送られる。このとき，上下左右のポイ ンタ移動コマンドが実行されれば, 動作時の振幅情報 $F_{I}(t)$ が動作閾值 $F_{\mathrm{th}}$ を超えている時間のみ $\mathrm{PC}$ 上のポインタ移動 が行なわれる. $F_{I}(t)$ が動作閾値 $F_{\mathrm{th}}$ を超えた時刻を $t_{1}$ とす ると, ポインタの移動速度はそのときの変化率情報 $F_{V}\left(t_{1}\right)$ に 比例して決定される，たとえば，操作者は動作 2 を素早く実 行し $F_{V}\left(t_{1}\right)$ を増加させることでポインタを早く移動させる ことができる。

・多動作モード $(K \geq 3)$

操作者が 3 つ以上の動作を実行可能であれば，第 1 の動作 を反転コマンドの切り替え, 第 2 の動作を現在の反転コマン ドの実行とし，第 3 以降の動作は反転コマンドの逆方向への 切り替えや，よく使うコマンド（たとえばダブルクリックな ど）に割り当てて制御可能である。また，9種類の動作が実 行できれば $(K=9)$, 全動作をコマンドごとに割り当てて制 御すること（たとえば動作 $1 \sim 4$ を 4 方向のポイン夕移動へ 対応させるなど）もできる。

(2) テキスト入力 ${ }^{4}$

Fig. 5 の [II]〜 [VII] に示される操作パネルでは，任意の文 字列を入力できる. Fig. 5 の [II] の 1 行目から 5 行目にかけて 配置されている各コマンドは入力可能な文字を表わしており, 最下位行に配置されている各コマンドは数字入力および漢字変 換・予測変換 ${ }^{4)}$ 候補の決定, 漢字変換候補リス卜 (Fig. 5 [IV]) のページ送り, 漢字入力, 無変換, 英字入力, カタカナ入力, 1 文字削除，全削除，メニューリスト (Fig. 5 [V]) への切り 替えを行なうためのコマンドである．操作者は漢字変換候補 (Fig. 5 [IV])，予測変換候補（Fig. 5 [III]）に数字付きで表示 される単語を最下位行の数字 (1)～(8) を選択して入力する. 漢字変換では漢字と読みに対応する仮名のデータベースに基 づいて, 入力と完全に一致する漢字への変換を行なう。予測 変換には文字列から単語を推定するために隠れマルコフモデ ル (Hidden Markov model; 以下, HMM) を用いている. 提案システムでは単語に対応する HMM を用意して各モデル に文字列を対応付けており，文字の入力ごとにすべてのモデ ル (単語) に対する事後確率を算出し, 予測単語候補を表示 する.

たとえば，「ありがとう」を入力する場合には，まず反転コ マンドが “あ”の位置で実行動作を行ない，予測変換・漢字 変換候補を表示させる。このとき，予測変換候補の(1)に「あ りがとう」が表示される（Fig. 5 [III]）ため，反転コマンド を最下位行の数字 “(1)”まで切り替え，実行動作を行なうこ とで目的とする「ありがとう」を入力することができる。ま た，“漢”の位置で実行動作を行なえば，Fig. 5 [IV]に表示さ れる漢字变換候補を最下位行の数字を用いて入力することも できる. 入力した文章は Fig. 5 の [V] に表示される.

また， [II] 中の “menu” のコマンドを選択することで，反 転コマンドはメニューリスト (Fig. 5 [VI]）に切り替わる. メ 


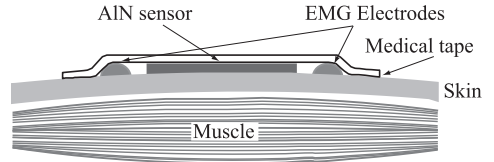

Fig. 6 Locations of electrodes for EMG measurement

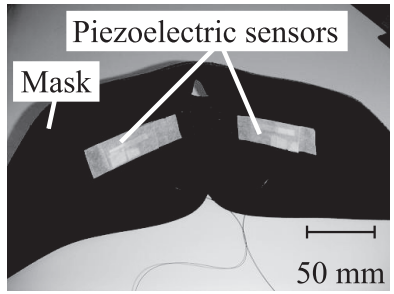

(a) The proposed mask with piezoelectric sensors

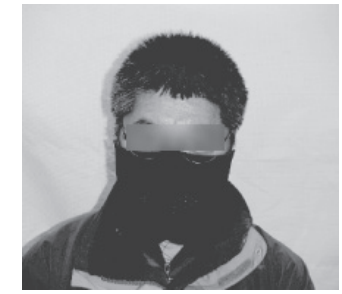

(b) A human operator with the proposed mask
Fig. 7 Mask-type interface using PC control

ニューリストには，入力した文章を任意のアプリケーション に転送できる文字転送コマンド，ポインタ制御とテキスト入 力の操作切替コマンド, アプリケーション起動やキーボード の操作が行なえるショートカットコマンドが配置されている. ショートカットコマンドは自由にカスタマイズ可能である.

テキスト入力では反転コマンドは横方向に自動的にスキャ ンする，そのため，1つの動作を実行できれば $(K=1)$, 入 力したい文字が反転したときにその動作を実行することによ り任意の文字を入力できる。また $K \geq 2$ の場合には，コマ ンドの実行と反転コマンドの切り替わり方向の変更などをそ れぞれの動作に割り当てて操作可能である. 反転コマンドの 切り替わり速度は動作時の变化率情報 $F_{V}\left(t_{1}\right)$ の值によって 低速 $\left(0<F_{V}\left(t_{1}\right) \leq 0.33\right)$ ，中速 $\left(0.33<F_{V}\left(t_{1}\right) \leq 0.67\right)$ ， 高速 $\left(0.67<F_{V}\left(t_{1}\right) \leq 1.0\right)$ の 3 段階に変更できるため, 操 作者は動作を素早く実行することで反転コマンドを早く移動 させることができる．Fig. 5 の [VII] には操作意図識別部で 得られた反転コマンド切り替わり速度と識別結果が表示され ており，操作者はこれらの情報を確認しながら操作を行なう。

\section{4. 筋動計測実験}

䈃状圧電センサを用いて筋動信号を計測し，筋動情報から 操作者の動作を推定できるか調査した。ここでは, 筋収縮の状 態を計測可能な EMG 信号と筋動信号を同時計測し，信号の 比較と動作推定精度の検証を行なった．実験は被験者に実験 の内容と目的を事前に十分説明し，同意を得た上で実施した。

\section{1 実験条件}

被験者は健常な男子大学生 5 名 $(\mathrm{A} \sim \mathrm{E}: 22.5 \pm 0.58$ 歳 $)$ と第 5 頝椎を損傷した ADL 全介助レベルの頸髄損傷患者 1 名（F：51 歳）の計 6 名とした. 筋動信号の計測には箔状圧 電センサとチャージアンプ (T-CAM001B, タートル工業), EMG 信号計測には $\mathrm{Ag} / \mathrm{AgCl}$ 皿電極 $(\mathrm{NT}-511 \mathrm{G}$, 日本光電) とマルチテレメータ (WEB-5000, 日本光電, 増幅率：1000 倍）を用いた. EMG 信号は左右の大㚘骨筋（Ch. 1：右煩，
Ch. 2 : 左煩) 付近の皮膚表面から計測し，同時に箔状圧電セ ンサを Fig. 6 に示すように医療用テープで貼付した。䇴状圧 電センサは 2 枚のシリコンゴムで挟んで用いた。また，防寒 用のマスク (Neoprene Half Mask, Balboa Manufacturing Co., LLC) の内側に Fig. 7 (a) に示すように䇴状圧電セン サを配置したマスク型インタフェースを開発して実験に用い た．䇴状圧電センサはセンサに加わる微細な圧力変動によっ て発生する電荷を出力電压として計測可能である ${ }^{9)}$. そのた め，皮膚に直接貼付する必要がなく，このようにマスクに装 着すれば操作者のセンサ脱着が容易になる (Fig. 7 (b) 参照).

実験では被験者に対して右㚘を動かす動作 $\left(\mathrm{M}_{1}\right)$, 左煩を動 か寸動作 $\left(\mathrm{M}_{2}\right)$, 両煩を動かす動作 $\left(\mathrm{M}_{3}\right)$ を行なわせ, 計測し た筋動情報と筋電信号を比較した。また，各被験者に 3 動作 を順に約 3 秒間程度維持させる試行をそれぞれ 11 試行行なわ せ，そのデー夕を無作為に学習デー夕 1 試行と検証デー夕 10 試行に分けて学習と識別を行なった。このとき，全チャネル の和が 1 となるように正規化した信号をパターンベクトルと し, $O_{\mathrm{th}}=1, H_{\mathrm{th}}=1.0$ とした。 なお，筋電位信号 $E M G_{l}(t)$ から次式に示す筋力情報 $F_{\mathrm{EMG}}(t)$ を算出し, 䇴状圧電センサ の振幅情報と比較した.

$$
F_{\mathrm{EMG}}(t)=\frac{1}{L} \sum_{l=1}^{L} \frac{E M G_{l}(t)-\overline{E M G_{l}^{\mathrm{st}}(t)}}{E M G_{l}^{\max }(t)-\overline{E M G_{l}^{\mathrm{st}}(t)}}
$$

ただし, $\overline{E M G_{l}^{\mathrm{st}}(t)}$ は安静時における $E M G_{l}(t)$ の時間平均, $E M G_{l}^{\max }(t)$ は事前に計測した各チャネルの最大随意収縮時 の值を表わす.

提案法に含まれるパラメータは事前に実施した予備実験よ り試行錯誤的に決定しており， $F_{\mathrm{th}}=0.25$, 䇴状圧電センサで は $V_{\mathrm{th}}^{+}=0.01 \mathrm{~V}, V_{\mathrm{th}}^{-}=-0.03 \mathrm{~V}$, マスク型インタフェースで は $V_{\mathrm{th}}^{+}=0.025 \mathrm{~V}, V_{\mathrm{th}}^{-}=-0.025 \mathrm{~V}$ とした. $V_{\mathrm{th}}^{+}, V_{\mathrm{th}}^{-}$はそれ ぞれ值を 0 から 0.005 刻みで増加させながら被験者に識別対 象動作を実施させ，意図した動作の発生を検出でき，かつ体 動などによる動作発生の誤判定が少ない值を用いた。信号計 測のサンプリング周波数は $f_{s}=1000 \mathrm{~Hz}$ とした. すなわち, 積分時間は $\frac{1}{f_{s}}=0.001 \mathrm{~s}$ となる.

なお，本実験はへルシンキ宣言に則り，被験者のインフォー ムド・コンセントを得て実施した。

\section{2 結果と考察}

Fig. 8 に被験者 $\mathrm{A}$ の皮膚表面に医療用テープで貼付した 箔状圧電センサから計測された皮膚側の筋動情報と EMG 信 号の一例を示す。図は $\mathrm{M}_{1}, \mathrm{M}_{2}, \mathrm{M}_{3}$ の順に 3 秒間動作の状 態を維持した際の筋動情報および EMG 信号であり，上から 順に筋動情報 $E_{l}(t), \mathrm{EMG}$ 信号 $E M G_{l}(t)$, 正規化した積分 情報 $\alpha_{l}(t)$, 正規化した積分筋電 $\beta_{l}(t)$, 振幅情報 $F_{I}(t)$, 筋力 情報 $F_{\mathrm{EMG}}(t)$, 各信号の識別結果を表わしている.

図から，筋収縮の開始時と終了時に計測した筋動情報が大 きく変化し，動作実施区間では 0 付近の值をとっていること がわかる．また，筋動信号の正規化積分情報 $\alpha_{l}(t)$ は，動作 開始時に立ち上がり，状態維持中は一定の值を出力後に動作 


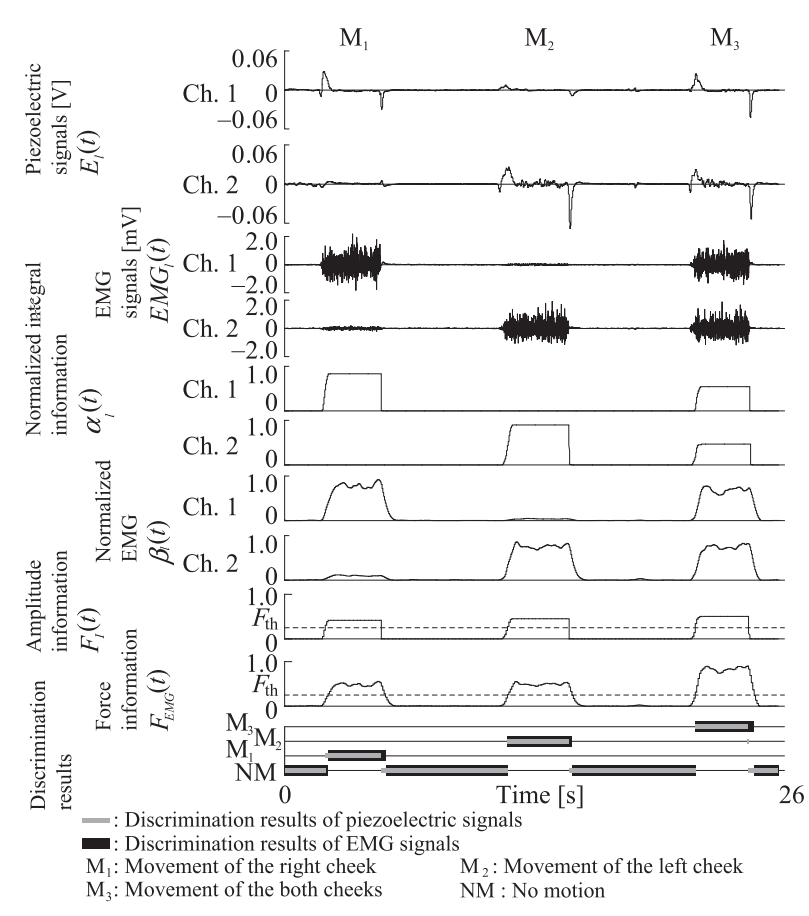

Fig. 8 Examples of the piezoelectric signals and EMG signals measurement

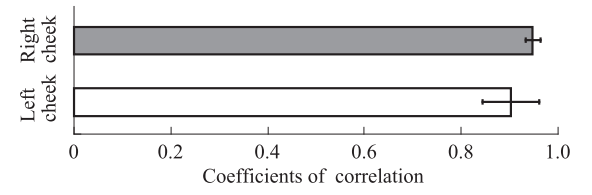

Fig. 9 Coefficient of correlation between normalized integral information and normalized EMG

終了時に 0 をとっている。これは EMG 信号から算出した 正規化した積分筋電 $\beta_{l}(t)$ に打いても同様の傾向を示してい る. Fig. 9 は正規化した積分情報 $\alpha_{l}(t)$ と正規化した積分筋 電 $\beta_{l}(t)$ の相関係数を表わしておう，各煩の相関係数はそれ ぞれ $0.95 \pm 0.02$ (右㚘), $0.90 \pm 0.06$ (左㚘) となり高い相 関が示された。これに対し，両者の平均絶対誤差はそれぞれ $0.21 \pm 0.09$ (右煩), $0.13 \pm 0.04$ (左頖) となった。 これは操 作者の意図しない動作によって生じる微細な変動の除去 $((1)$ 式）㧍よび不感帯（(4) 式）による影響であると考えられるた め, より効果的な信号処理・特徴抽出処理方法については今 後検討が必要である。

また，振幅情報 $F_{I}(t)$ おうよ゙筋力情報 $F_{\mathrm{EMG}}(t)$ が $F_{\mathrm{th}}$ を 超えた全時刻に打いて識別を行ない，各動作を正しく識別で きた割合を各試行ごとに求め，その全 10 試行の平均值とし て算出した平均識別率はそれぞれ $99.33 \pm 1.01 \%, 100 \%$ と なった. Fig. 10 はこのときの平均識別率と，マスク型イン タフェースを用いて同様に 3 動作の計測と識別を行なった 結果を示している，マスク型インタフェースの平均識別率は $99.83 \pm 0.25 \%$ となり，精度良く動作の識別が行なえることが 示された.

このとき使用した各センサの脱着時間の全被験者平均は

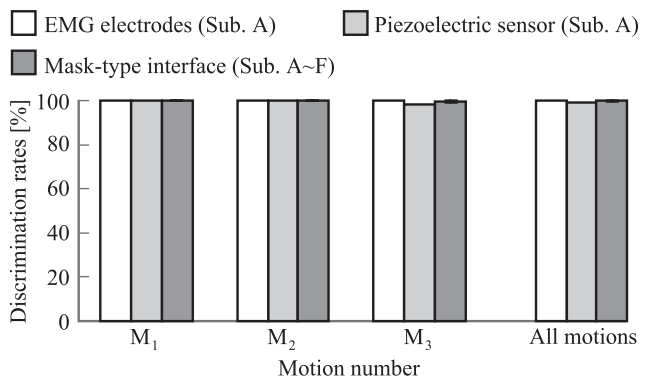

Fig. 10 Average discrimination rates for each sensor

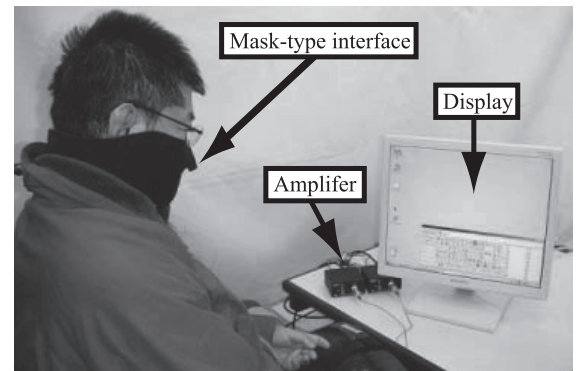

Fig. 11 Operation scene of the proposed system (Subject F)

マスク型インタフェースが $16.85 \pm 4.80 \mathrm{~s}, \mathrm{EMG}$ 電極が $182.55 \pm 18.23 \mathrm{~s}$ となった。ここで $\mathrm{EMG}$ 電極は個々の電 極をペーストを貼付して着脱しなければならず，医療用テー プなどの貼付も含めて脱着時間が長くなったと考えられる. これに対して，たとえば EMGの計測に無線型アクティブ電 極を用いることで脱着時間を低減できる可能性はあるが，マ スク型インタフェースはあらかじめマスクに箔状圧電センサ を取り付けており，マスクを装着するわずかな時間で計測が 可能となる．箔状圧電センサは非常に小型・軽量で高感度な ため，このようにマスクに装着して使用することで脱着が容 易なインタフェースに利用可能である。

\section{5. $\mathrm{PC}$ 操作実験}

\section{1 実験条件}

被験者を頸髄損傷患者を含む 3 名 $(\mathrm{D} \sim \mathrm{F})$ とし， $\mathrm{PC}$ 操作 実験を行なった。被験者はマスク型インタフェースを装着し $\mathrm{PC}$ 操作を行なう。使用する動作は, 右㚘 $\left(\mathrm{M}_{1}\right)$, 左㚘 $\left(\mathrm{M}_{2}\right)$, 両煩 $\left(\mathrm{M}_{3}\right)$ を動かす 3 動作とし，ポインタ制御では $\mathrm{M}_{1}$ を “カーソル上移動”, $\mathrm{M}_{2}$ を “カーソル下移動”, $\mathrm{M}_{3}$ を “決定” に，テキスト入力では $\mathrm{M}_{1}$ を“行間移動”, $\mathrm{M}_{2}$ を“遷移方向の 変更”， $\mathrm{M}_{3}$ を“決定”とした。各種パラメー夕は予備実験よ り $f_{s}=1000 \mathrm{~Hz}, F_{\mathrm{th}}=0.25, V_{\mathrm{th}}^{+}=0.025 \mathrm{~V}, V_{\mathrm{th}}^{-}=-0.025 \mathrm{~V}$, $O_{\mathrm{th}}=100$ 回とした。また $H_{\mathrm{th}}$ は被験者 $\mathrm{D}, \mathrm{F}$ は 0.2 , 被験 者 $\mathrm{E}$ は 0.3 とした。ポインタの初期位置はディスプレイの中 心とし，テキスト入力におけるカーソルの移動速度は一定と した。使用したコンピュータは CPU：Intel(R) Pentium(R) 4, クロック周波数: $3.20 \mathrm{GHz}$,メモリ $: 2.0 \mathrm{~GB}$ であり，画面 の解像度は $1024 \times 728$ piexl とした。試行回数は被験者 D, $\mathrm{E}$ が 2 回, 被験者 $\mathrm{F}$ が 10 回とした。 


\section{2 操作例}

前述のように，インターネットによるホームページの閲覧 は PC 利用の大きな割合を占める。そこで本論文では一般的 な PC の使用ケースを想定し, 被験者に提案システムを用い てWeb 上の検索エンジンで以下の (i) (vi) の手順で「天気」 という単語を検索するよう指示した。 まず (i) ポインタ制御 により指定したアイコンまでポインタを移動し, (ii) インター ネットブラウザ (検索エンジン) を開いた後に (iii) テキスト入 力モードへ切り替えを行なう。そして，(iv) 文字 “て”を入力

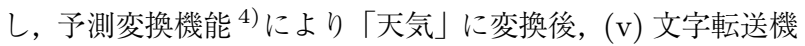
能により生成した文章を転送し，(vi) キーボードの “Enter” に対応するショートカットコマンドにて検索を実行する.

Fig. 11 に被験者 F（頸髄損傷患者）が提案システムを用い て PC 操作を行なっているようすを, Fig. 12 およびFig. 13 に実験結果を示す．Fig. 12 はポインタ制御時の結果を示して おり, 上から順に, 筋動情報 $E_{l}(t)$, 変化率情報 $F_{V}(t)$, 振幅 情報 $F_{I}(t)$, 操作パネル上のカーソル位置, ポインタ移動量 を表わしている. Fig. 13 は時刻 (i)〜 (iii) およびテキスト入 力におけるディスプレイのようすである．また，Fig. 13 (e) にはディスプレイの一部を左上に拡大表示している.

Fig. 12 では，まず $\mathrm{M}_{1}$ を行なうことで操作パネル上のカー ソルを移動し, ポインタの左方向への移動に対応するコマンド を選択している． $2.1 \mathrm{~s}$ 付近で $\mathrm{M}_{3}$ を行なうことで選択してい るコマンドが決定され, ポインタが横軸方向へ移動しているこ とがわかる. 同様に $\mathrm{M}_{1}$ によりカーソルを選択後, $\mathrm{M}_{3}$ を行な うことで移動方向を決定し, $9.5 \mathrm{~s}$ 付近でポインタを指定した アイコン位置まで移動させている (Fig. 12 (i), Fig. 13 (a)). また, Fig. 12 (a)の院影部では, $\mathrm{M}_{3}$ を行なったときの変化 率情報 $F_{V}(t)$ の大きさに応じてポインタの移動量の傾きが変 化しており，ポイン夕速度が変化している． $12.0 \mathrm{~s}$ 付近で “D クリック”と表示されたコマンドを選択，決定することでア プリケーション（Windows ${ }^{\circledR}$ Internet Explorer ${ }^{\circledR}$ ) を起動 し (Fig. 12 (ii), Fig. 13 (b)), コマンドの選択, 決定を繰り 返して $15.0 \mathrm{~s}$ 付近で操作をテキスト入力へ切り替えている (Fig. 12 (iii), Fig. 13 (c)).

テキスト入力画面では, まず $\mathrm{M}_{1}$ を繰り返し行ない母音カー ソル位置を “え” 行まで移動させている. そして, 横方向に 一文字ずつ自動遷移するカーソルが “て”の位置になったと きに $\mathrm{M}_{3}$ を行なって文字を入力している (Fig. 13 (d)). 文字 を入力すると同時に予測変換機能によって予測された文字が 画面右に表示される，操作者はカーソルが “(1)”の位置にあ るときに $\mathrm{M}_{3}$ を行なうことで文字 “て”を「天気」に変換して いる。つぎに操作者は $\mathrm{M}_{3}$ を行なうことで “menu” コマンド を選択し，アプリケーションへの文字転送（Fig.13 (e)）を 行なっている. そして “Enter” のショートカットコマンドを 選択することで検索（Fig. 13 (f)）を実施している.

同様に，与えられたタスクを完了するまでに要した時間お よび操作回数の平均值は被験者 D がそれぞれ $45.9 \pm 0.77 \mathrm{~s}$, $25.5 \pm 6.36$ 回, $\mathrm{E}$ が $32.3 \pm 3.58 \mathrm{~s}, 31.5 \pm 2.12$ 回, $\mathrm{F}$ が

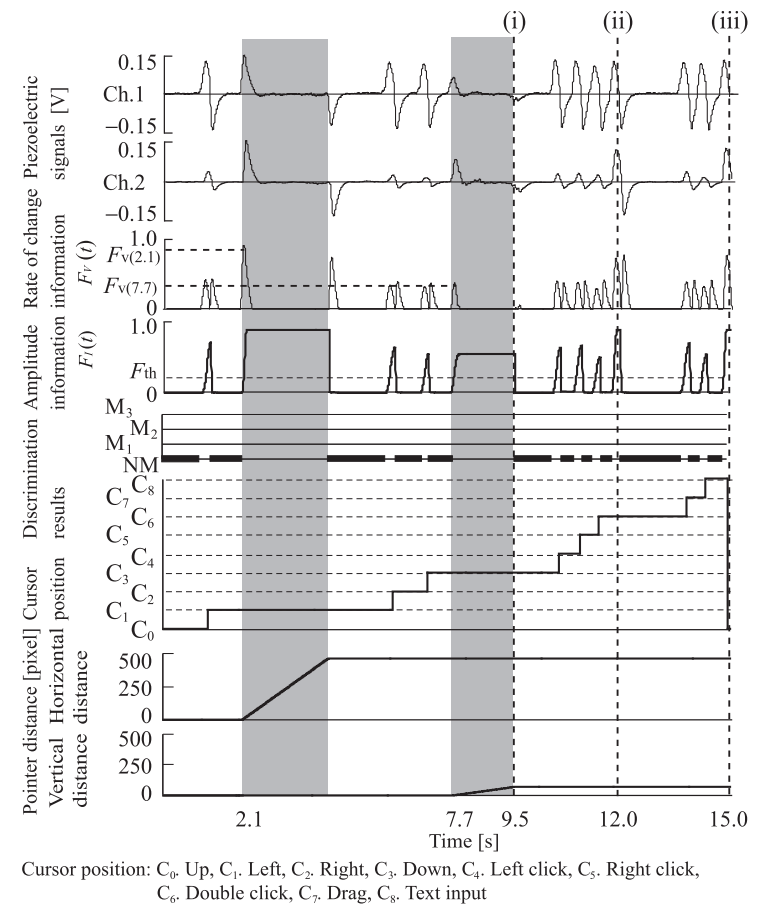

Fig. 12 Examples of the $\mathrm{PC}$ operation experiments (Subject F)

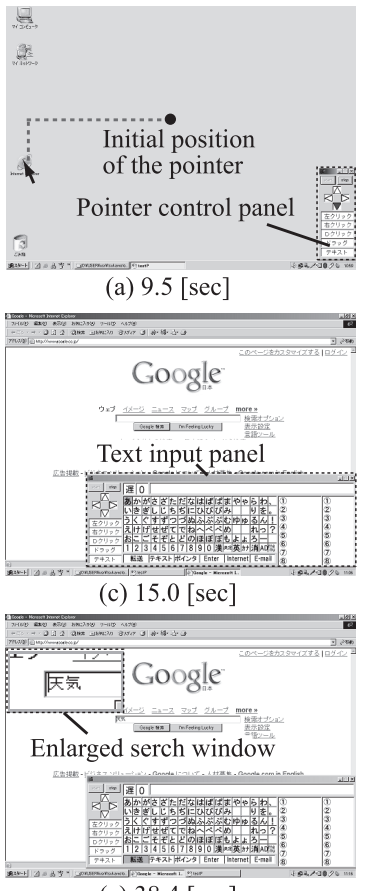

(e) $38.4[\mathrm{sec}]$

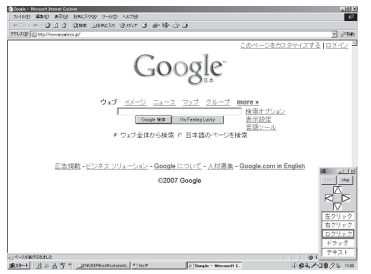

(b) $12.0[\mathrm{sec}]$

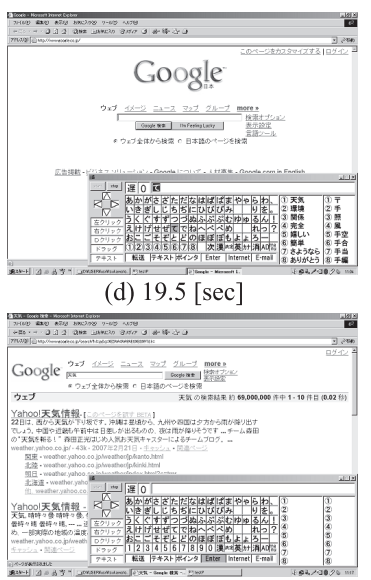

(f) $41.6[\mathrm{sec}]$
Fig. 13 Examples of display during operation experiments

$65.5 \pm 12.43 \mathrm{~s} ， 34.4 \pm 5.08$ 回であった。全被験者ともに夕 スクの成功率は $100 \%$ あったことから，提案システムを用 いることで被験者が PC を任意に操作可能なことが示された.

\section{3 変化率情報 $F_{V}(t)$ の調節能力}

提案システムの操作性は, たとえばポインタをどの程度素 早く目的位置へ移動できるかなどに大きく影響される。ポイ 


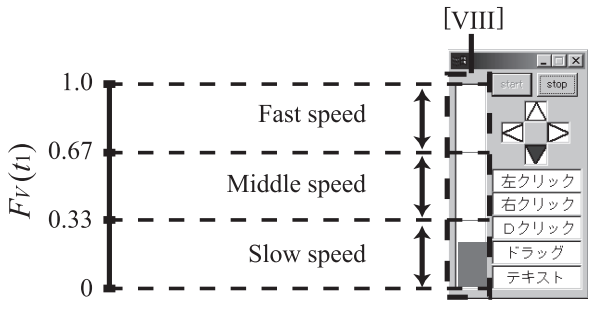

Fig. 14 Pointer control panel used for the speed control experiments

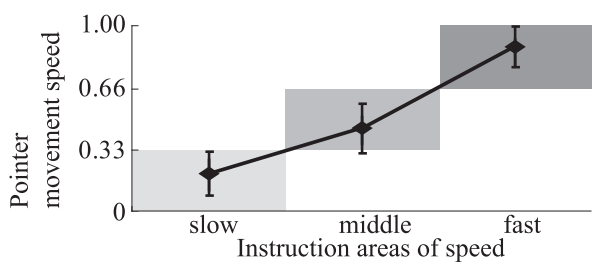

Fig. 15 Results of the speed control experiments

ンタの移動速度は変化率情報 $F_{V}(t)$ の大きさに応じて決定さ れるため，ここでは被験者の変化率情報 $F_{V}(t)$ の調節能力に ついて検証した.

被験者は口元の動きを利用した筋電操作型インタフェース ${ }^{4)}$ の操作経験者 $\mathrm{B} \sim \mathrm{D}$, および未経験者 $\mathrm{E}$ の計 4 名とし, Fig. 14 に示すポインタ操作パネルを用いて実験を行なった。実験で は変化率情報 $F_{V}\left(t_{1}\right)$ の大きさに応じてポインタの移動速度 を均等に 3 等分する場合を想定した. 3 等分した速度をそれ ぞれ高速, 中速, 低速とし, 変化率情報を調節して各速度に 合わせるよう指示した. Fig. 14 中の [VIII] はポインタの各 移動速度に対応する変化率情報の大きさを表わしている．変 化率情報を各速度領域に 1 回ずつ調節する夕スクを 1 試行と して計 10 試行行なわせた.

Fig. 15 に結果を示す. 図は各速度領域における $F_{V}\left(t_{1}\right)$ の 全 40 試行の平均と標準偏差を示している. 図の陰影部は各 速度に対応した $F_{V}\left(t_{1}\right)$ の範囲である。結果より, 変化率情 報 $F_{V}\left(t_{1}\right)$ の平均值が提示した速度範囲内にあり, 3 段階の調 節が行なえていることが確認できる。このとき，指示どおり に調節を行なえた割合は低速に対応する領域が $80 \pm 24.5 \%$ ， 中速が $75 \pm 10.0 \%$ ，高速が $100 \%$ となり，低速および中速の 正答率が低くなった。これは, 各被験者が煩の動作において 微妙な素早さの変化をつけることが難しく, 低速領域と中速 領域に対応する動作を上手く再現できなかったと考えられる. 今回の結果は 2 段階程度であれば変化率情報 $F_{V}\left(t_{1}\right)$ を随意 的に調節可能であることを示しているため，たとえば変化率 情報をポインタの移動速度に線形的に対応させることで, 高 速・低速を切り替えられる可能性がある。より詳細な速度の 制御には, たとえば事前に操作者の力の強弱のばらつきを取 得し, それに合わせて非線形的に速度を対応させるなどの検 討が必要である。

\section{6. まと め}

本論文では䇴状圧電センサを用いた筋動信号の計測方法を 提案し，筋動情報による PC 操作システムを開発した。提案 システムは箔状圧電センサを取り付けたマスク用いて煩の筋 動信号を計測し, 筋動の強さと速さの傾向を抽出・識別するこ とで少ない動作数で PC のポインタ制御やテキスト入力が可 能である。実験では圧電信号と EMG 信号の同時計測を行な い，䇴状圧電センサを用いて筋の動きを計測できることを示

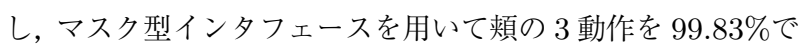
識別可能なことを明らかにした。また，頸髄損傷患者がポイ ンタ制御やテキスト入力などの PC 操作を行なえることを確 認した。

今後は各種パラメータの適切な決定法などを検討し，ユー ザビリティの高いシステムの開発を目指す.

謝辞 本論文のデー夕収集にご協力いただきました小林勝 氏，塚本隼平氏に深く感謝の意を示します。

\section{参 考 文 献}

1) G. Pfurtscheller, J. Kalcher, D. Flotzinger and M. Pregenzer: On-Line EEG Classification during ExternallyPaced Hand Movements Using a Neural Network-Based Classifier, Electroencephalography and Clinical Neurophysiology, 99-5, 416/425 (1996)

2) K. Tanaka, K. Matsunaga and H.O. Wang: Electroencephalogram-Based Control of an Electric Wheelchair, IEEE Transactions on Robotics, 21-4, 762/766 (2005)

3) L. Citi, R. Poli, C. Cinel and F. Sepulveda: P300-Based BCI Mouse with Genetically-Optimized Analogue Control, IEEE Transactions on Neural Systems and Rehabilitation Engineering, 16-1, 51/61 (2008)

4) 过, 重藤, 岡本，杉山，柴：筋電位信号で操作可能なテキス 卜入カシステム, ヒューマンインタフェース学会論文誌, 9-2, 97/104 (2007)

5) K. Shima, M. Okamoto, N. Bu and T. Tsuji: Novel Human Interface for Game Control Using Voluntarily Generated Biological Signals, Journal of Robotics and Mechatronics, 18-5, 626/633 (2006)

6) K. Arai and R. Mardiyanto: Eyes Based Eletric Wheel Chair Control System: I (eye) can control Electric Wheel Chair, International Journal of Advanced Computer Science and Applications, 2-12, 98/105 (2011)

7) A. Bulling, D. Roggen and G. Troster: EyeMote: Towards context-aware gaming using eye movements recorded from wearable electrooculography, Proceedings of Second International Conference on Fun and Games, 33/45 (2008)

8）谷口, 西川, 宮崎：こめかみスイッチ：アフォーダンスを考慮 した常時装着型コマンド入力装置の設計と実装, 計測自動制御 学会論文集，46-1, 39/48 (2010)

9）上野，秋山，池田，立山：窒化アルミニウム薄膜を用いた箔 状フレキシブル圧カセンサ, 計測自動制御学会論文集, 38-5, 427/432 (2002)

10) N. Bu, J. Tsukamoto, N. Ueno, K. Shima and T. Tsuji: Measuring Muscle Movements for Human Interfaces Using a Flexible Piezoelectric Thin Film Sensor, Proceedings of the 30th Annual International Conference of the IEEE Engineering in Medicine and Biology Society, 112/116 (2008)

11) T. Tsuji, O. Fukuda, H. Ichinobe and M. Kaneko: A LogLinearized Gaussian Mixture Network and Its Application 
to EEG Pattern Classification, IEEE Transactions on Systems, Man, and Cybernetics-Part C: Application and Reviews, 29-1, 60/72 (1999)

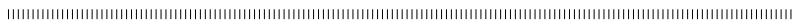

\section{[著 者 紹 介]}

島圭介（正会員）

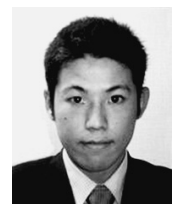

2005 年広島大学工学部第二類卒業. 2007 年同大 学大学院工学研究科博士課程前期修了. 2009 年同 博士課程後期修了。2007 2008 年日本学術振興会 特別研究員 (DC1).2009 年同特別研究員 (PD) を経て, 2012 年横浜国立大学大学院工学研究院 助教, 現在に至る. 博士 (工学). 生体信号解析, ニューラルネット，ヒューマンインタフェースな どの研究に従事. IEEE などの会員.

\section{杉 江 研 勇}

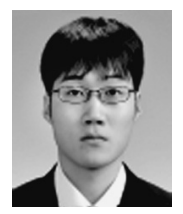

2011 年広島大学工学部第二類卒業. 現在, 同大 学大学院工学研究科システムサイバネティクス専 攻博士課程前期に在学中. 生体信号解析, ヒュー マンインタフェースに関する研究に従事.

芝 軒太 郎

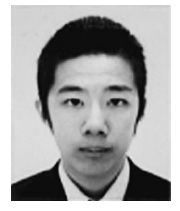

2008 年徳島大学工学部知能情報工学科卒業. 2010 年広島大学大学院工学研究科博士課程前期 修了. 2012 年同博士課程後期修了. 日本学術振興 会特別研究員 (DC2) を経て, 現在，同特別研究 員 (PD). 博士 (工学). 生体信号解析, 次元削減, マン・マシン・インタフェースなどの研究に従事. IEEE などの会員

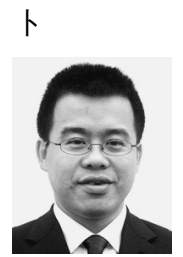

楠

1988 年中国大連理工学大学機械工学科卒業. 2001 年同大学大学院機械工学専攻修了. 2005 年 広島大学大学院工学研究科博士課程後期修了。 ま た同年，産業技術総合研究所研究員. 2010 年, 熊 本高等専門学校制御情報システム工学科准教授, 現在に至る。ニューラルネット，パターン識別, 生体信号解析, ニューロチップなどの研究に従事. IEEE の会員。

\section{上 野 直 広 (正会員)}

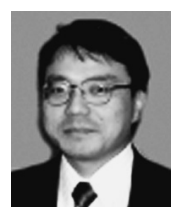

1984 年九州大学理学部物理学科卒業. 同年防衛 庁技術研究本部第 5 研究所. 85 年福岡県庁建築都 市部. 90 年通商産業省工業技術院九州工業技術試 験所入所（現（独）産業技術総合研究所），現在に 至る. また, 2008 年広島大学大学院工学研究科シ ステムサイバネティクス専攻客員教授．博士（工 学).アクティブセンシング, 機能性材料のデバイ ス化, 水素エネルギーシステムなどの研究に従事. IEEE の会員。

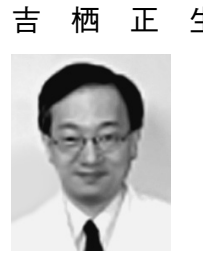

1981 年東京大学医学部医学科卒業. 96 年同大 学医学部老年病科助手・医局長を経て，2002 年よ り広島大学大学院医歯薬学総合研究科心臟血管生 理医学教授, 現在に至る. 博士 (医学). 血管生物 学・動脈硬化, 循環器学, 老年医学などの研究に 従事. 日本循環器学会, 日本動脈硬化学会, 日本 高血圧学会, 日本老年医学会, 日本内科学会など の会員.

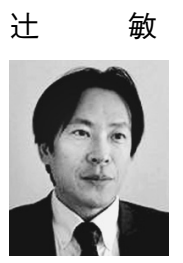

敏 夫（正会員）

1985 年広島大学大学院工学研究科博士課程前期 修了. 同年広島大学工学部助手. 94 年同助教授を 経て, 2002 年同大学大学院工学研究科教授, 現在 に至る。工学博士。人間とロボットの運動制御, ニューラルネット，マン・マシンシステムなどの 研究に従事. IEEE，日本人間工学会，バイオメカ ニズム学会, 日本機械学会などの会員. 